\title{
Determination of the Age of Municipal Solid Waste through Soil Tests
}

\author{
Udeni. P. Nawagamuwa and Jayabalasingham Thirojan
}

\begin{abstract}
Evaluation of the geotechnical properties of Municipal Solid Waste (MSW) is troublesome due to heterogenic nature and the changes in such properties due to degradation with time. Previously abandoned dump yards in Sri Lanka are now being used for construction activities due to the shortage of lands in urban localities. However, the properties of such degraded MSW vary and the actual age of such MSW governs the properties. MSW samples of known age were collected from three dump sites, Kallundai in Jaffna, Karadiyana in Colombo and Matara, Sri Lanka. Particle size distribution, specific gravity, Atterberg limits, Proctor compaction, permeability and direct shear tests were conducted on ten samples in order to observe the variation of geotechnical properties with age. Gravel percentage ( $40 \%$ to $12 \%)$, liquid limit (61\% to $17 \%)$, plastic limit (36\% to $15 \%)$, plasticity index $(24 \%$ to $1 \%)$, optimum moisture content $(47 \%$ to $16 \%)$, hydraulic conductivity $\left(1.8 \times 10^{-5} \mathrm{~m} / \mathrm{s}\right.$ to $1.3 \times 10^{-6} \mathrm{~m} / \mathrm{s}$ ) and organic content show decreasing trend with time, while sand percentage $(55 \%$ to $78 \%$ ), silt and clay percentage ( $4 \%$ to $20 \%$ ), specific gravity (1.66 to 2.38 ), maximum dry density (933 $\mathrm{kg} / \mathrm{m}^{3}$ to $1714 \mathrm{~kg} / \mathrm{m}^{3}$ ) and waste homogeneity show increasing trend. Some data was collected from published literature to compare the results of the present study. This paper highlights the importance of the changes in the geotechnical properties of MSW with fill age when constructing on such grounds.
\end{abstract}

Keywords: $\quad$ Age of MSW, Soil tests, Geotechnical properties, Particle size, Specific gravity

\section{Introduction}

Most number of MSW (Municipal Solid Waste) dump sites in Sri Lanka is located in the city centers, and some of these have been abandoned due to public pressure and environmental issues, while some had even reached their design capacities. Due to the increase in the population growth in major cities like Colombo, Kandy and Jaffna, rapid development and urbanization has caused scarcity of lands available for new construction. Therefore, the abandoned and design capacity reached dump sites are now being used for new construction for further development of these cities. Further, these dumped wastes eventually transform into soil, and can be used as economical materials for construction related activities in a developing country like Sri Lanka.

The objective of this research is to find out the variations of the geotechnical properties of MSW with the fill age through soil tests. It is important to know the variations of the geotechnical properties of MSW with fill age, to safely design and construct buildings on the above-mentioned MSW dump sites.

\section{Literature Review}

Globally also, there is an increasing tendency to construct buildings on design capacity reached landfills. As MSW consists of highly organic materials, it will undergo several phases of degradation [1] to [4]). Due to these changes and heterogenic nature, geotechnical properties of MSW show a tendency to vary with the age of fill. Therefore, it is important to study the variation of geotechnical properties of MSW with respect to the age of fill in order to study the adverse effects of dump sites such as settlement, slope instability and shear failure, when constructing on the design capacity reached landfills.

MSW, commonly known as trash or garbage, is household waste and typically consists of food

Eng. (Dr.) Udeni. P. Nawagamuwa, FIE(SL), BScEng.Hons (Moratuwa), MEng (AIT), DrEng (YNU),

CEng, Senior Lecturer, Department of Civil Engineering,

University of Moratuwa.

Email:udeni@uom.lk

ORCID ID: $h$ ttp://orcid.org/0000-0002-3472-6622

Eng. Jayabalasingham Thirojan, AMIE(SL),

BScEng.Hons (Moratuwa), MIESAMSSE(SL),

Resident Engineer (Geo), RCY Pte Ltd, Singapore.

Email:thirojan2010@gmail.com

ORCID ID: $h$ ttp://orcid.org/0000-0002-2367-8346 
and garden waste, paper products, plastics, rubber, textile, wood, ash, and soil [1], [5]). These components are different in size, shape, compressibility, tensile strength and degradability [1]. The composition of MSW generally varies from country to country, region to region and period to period. Even within a particular landfill with similar MSW input, the composition of MSW varies with its fill age due to the degradation process of organic matter. The composition of the waste, moisture content, organic matter content, permeability, particle size distribution and specific gravity are considered as important MSW characteristics. These parameters greatly influence the geotechnical characteristics of the waste. Therefore, there is a need to understand the MSW characteristics with decomposition and degradation with time.

\section{Sample Collection and Experimental Program}

In this research, an attempt was made to find out a relationship between some geotechnical properties and the fill age of MSW. For that purpose, sampling was done at three dump sites, Kallundai in Jaffna and Karadiyana in Colombo and Matara. These three locations are shown in Figure 1, Map of Sri Lanka. A total of 10 MSW samples were collected from the above-mentioned locations: 7 samples from Kallundai in Jaffna; 2 Samples from Karadiyana in Colombo; and 1 sample from Matara. The depth of the samples ranged from $1 \mathrm{~m}$ to $3 \mathrm{~m}$ for Kallundai samples, and $1 \mathrm{~m}$ to $2 \mathrm{~m}$ for Karadiyana and Matara samples. All the collected MSW samples were disturbed samples.

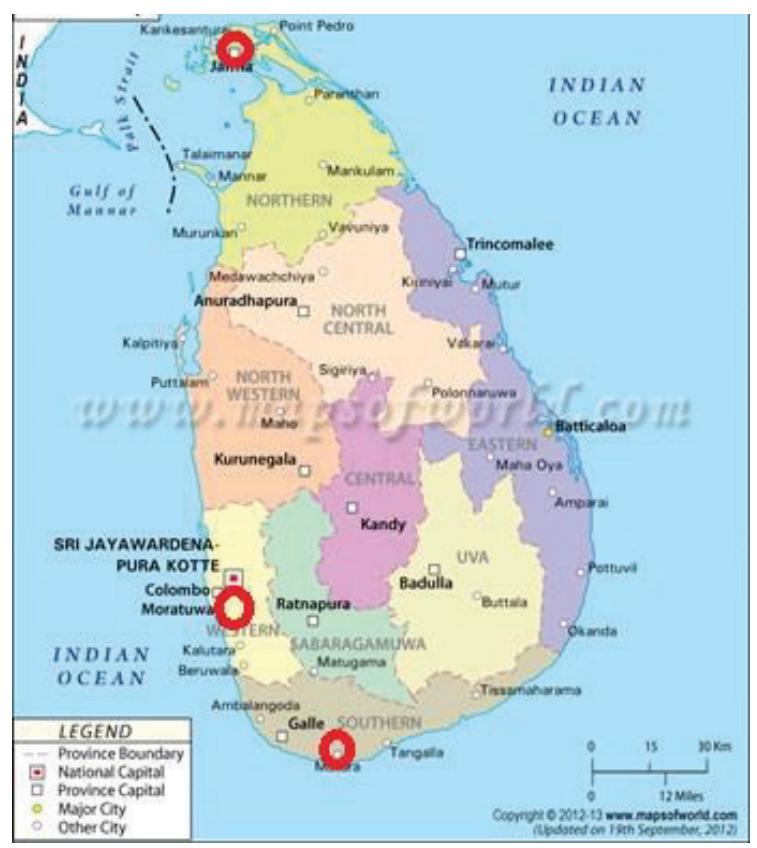

Figure 1 - Map of Sri Lanka with 3 Selected Dump Sites (www.mapofworld.com) [6]

A number of tests were carried out in the laboratory to investigate the properties of MSW with age. Standards mentioned in Table 1 were followed in the experimental studies where applicable.

Table 1 - Standards Followed in the Experimental Studies

\begin{tabular}{|l|l|}
\hline Test & Reference number \\
\hline Standard test method for particle size analysis of soils [7] & ASTM D 422 \\
\hline Standard test method for moisture-density relations of soils [8] & ASTM D 698 \\
\hline Standard test method for specific gravity of soils [9] & ASTM D 854 \\
\hline Standard test method for permeability of granular soils (constant head) [10] & ASTM D 2434 \\
\hline $\begin{array}{l}\text { Standard test method for direct shear test of soils under consolidated drained } \\
\text { conditions [11] }\end{array}$ & ASTM D 3080 \\
\hline $\begin{array}{l}\text { Standard test method for liquid limit, plastic limit and plasticity index of soils } \\
{[12]}\end{array}$ & ASTM D 4318 \\
\hline
\end{tabular}

\section{Experimental Results and Discussion}

\subsection{Particle Size Distribution}

Shariatmadari et al., 2014 [13], Wu et al., 2012 [14] and Machado et al., 2010 [15] had concluded that gravel content decreases while sand and silt contents increase with the fill age of MSW. A similar result of particle size distribution with the age is observed in the present study and confirmed the direction of the arrowhead indicating the increase in the age as shown in Figure 2. 
Results of combined sieve and hydrometer analysis of the collected samples are shown in Figure 2. Variation of $D_{60}, D_{30}$, and $D_{10}$ are illustrated in Figure 3, in which $\mathrm{D}_{60}$ exhibits a significant decrease, $D_{30}$ a slight decrease and $D_{10}$ no significant variation with fill age. The uniformity coefficient $(\mathrm{Cu})$, curvature coefficient $(C c)$ and the effective size (D10) are the grading characteristics of the soil. These are the geometric properties of a grading curve that describe a particular type of soil. The variation of $C_{c}$ and $C_{u}$ are shown in Figure 4 , in which $C_{u}$ exhibits a significant decrease while $C_{c}$ shows no significant variation with the fill age. These results conclude a poorly graded soil according to the USCS. Figure 5 shows the variation of percentages of soil components such as gravel, sand and silt and clay according to USCS and it can be observed that the gravel content is decreasing while sand and 'silt and clay' contents are increasing with the fill age of MSW.

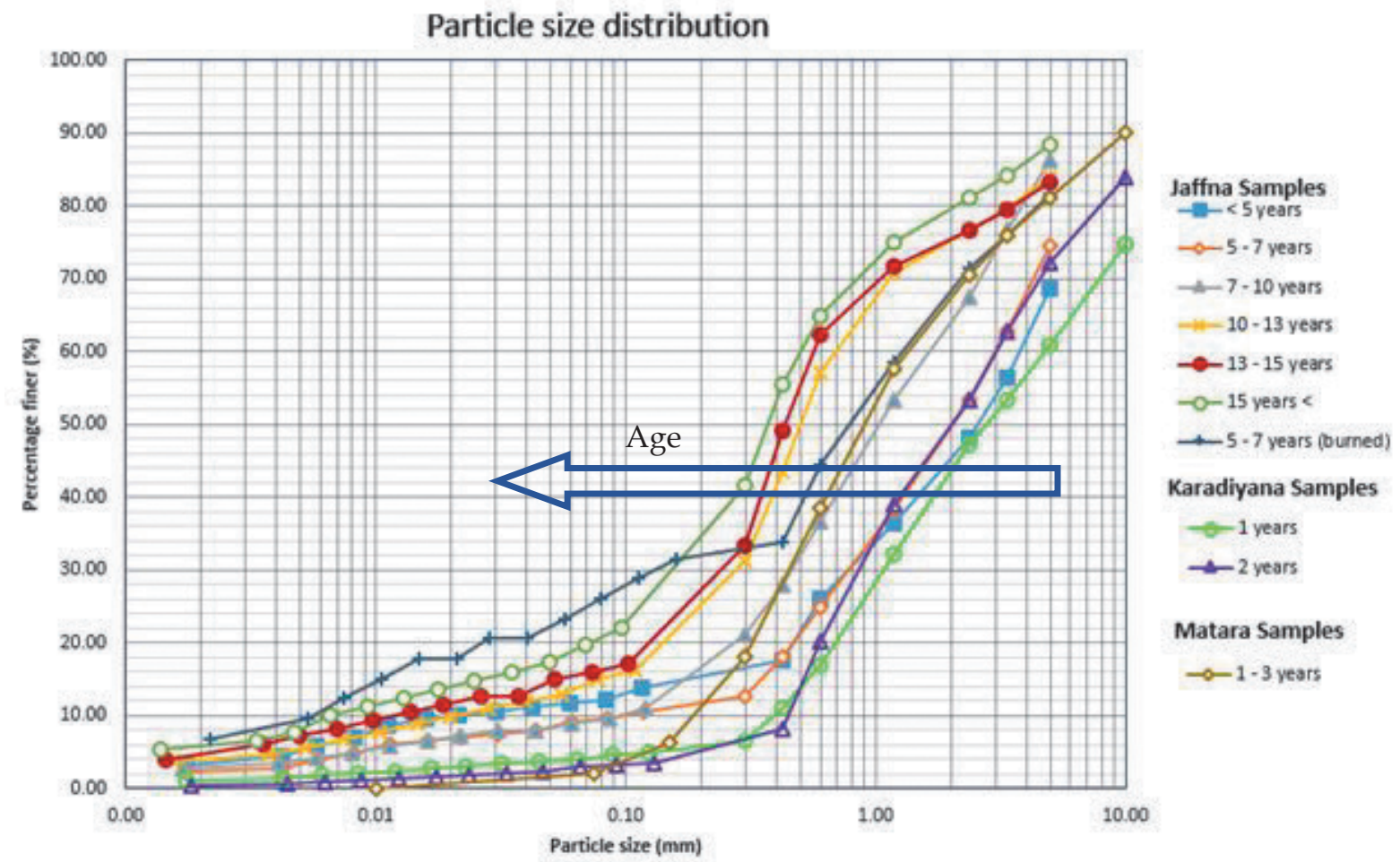

Figure 2 - Particle Size Distribution of Tested MSW Samples

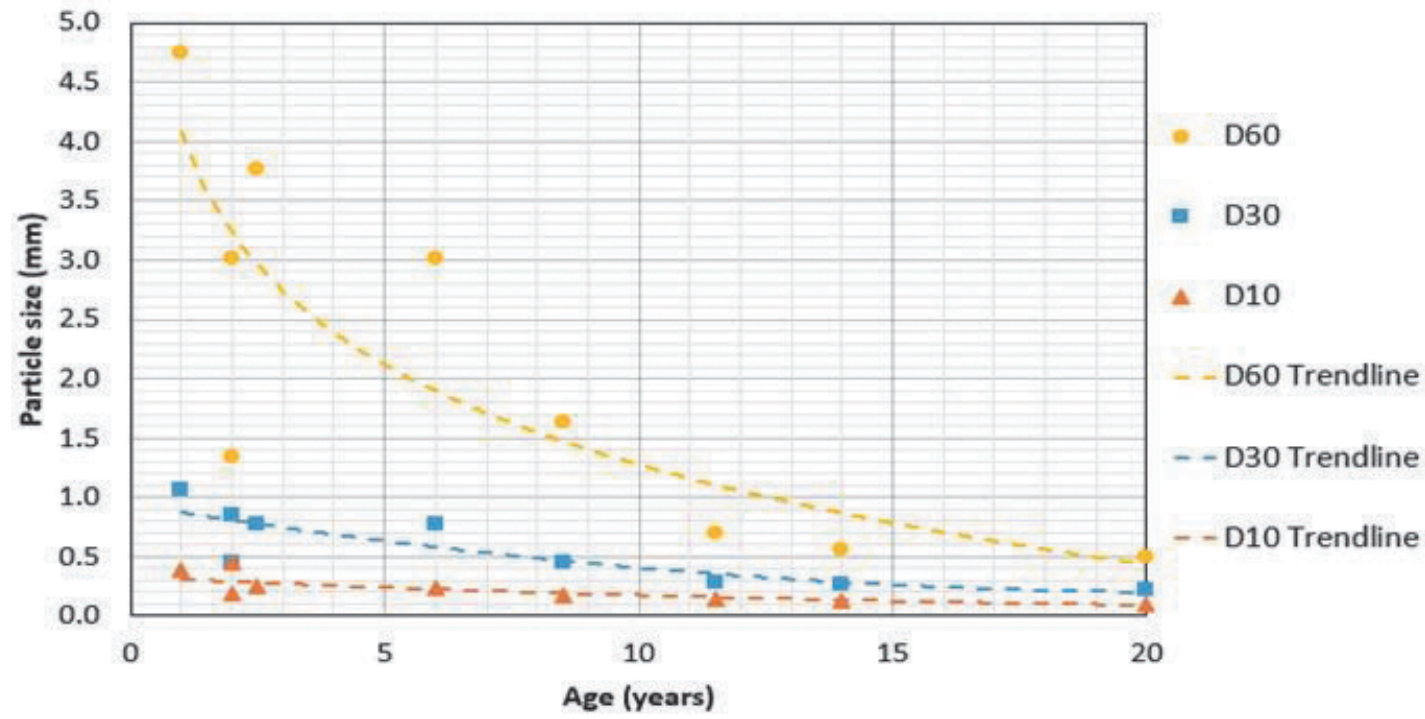

Figure 3 - Variation of $D_{60}, D_{30}$ and $D_{10}$ with Age of MSW 


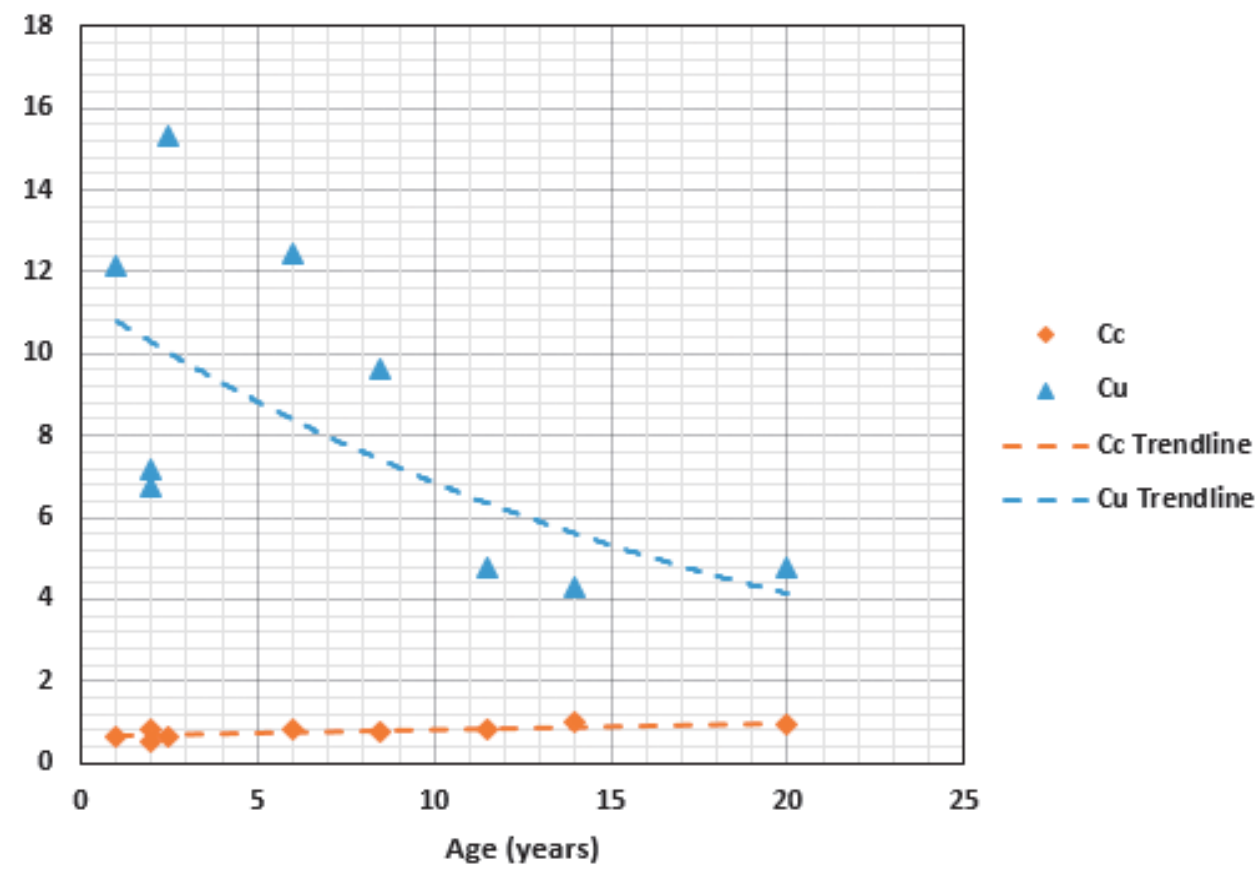

Figure 4 - Variation of $\mathrm{C}_{c}$ and $\mathrm{C}_{\mathrm{u}}$ with Age of MSW

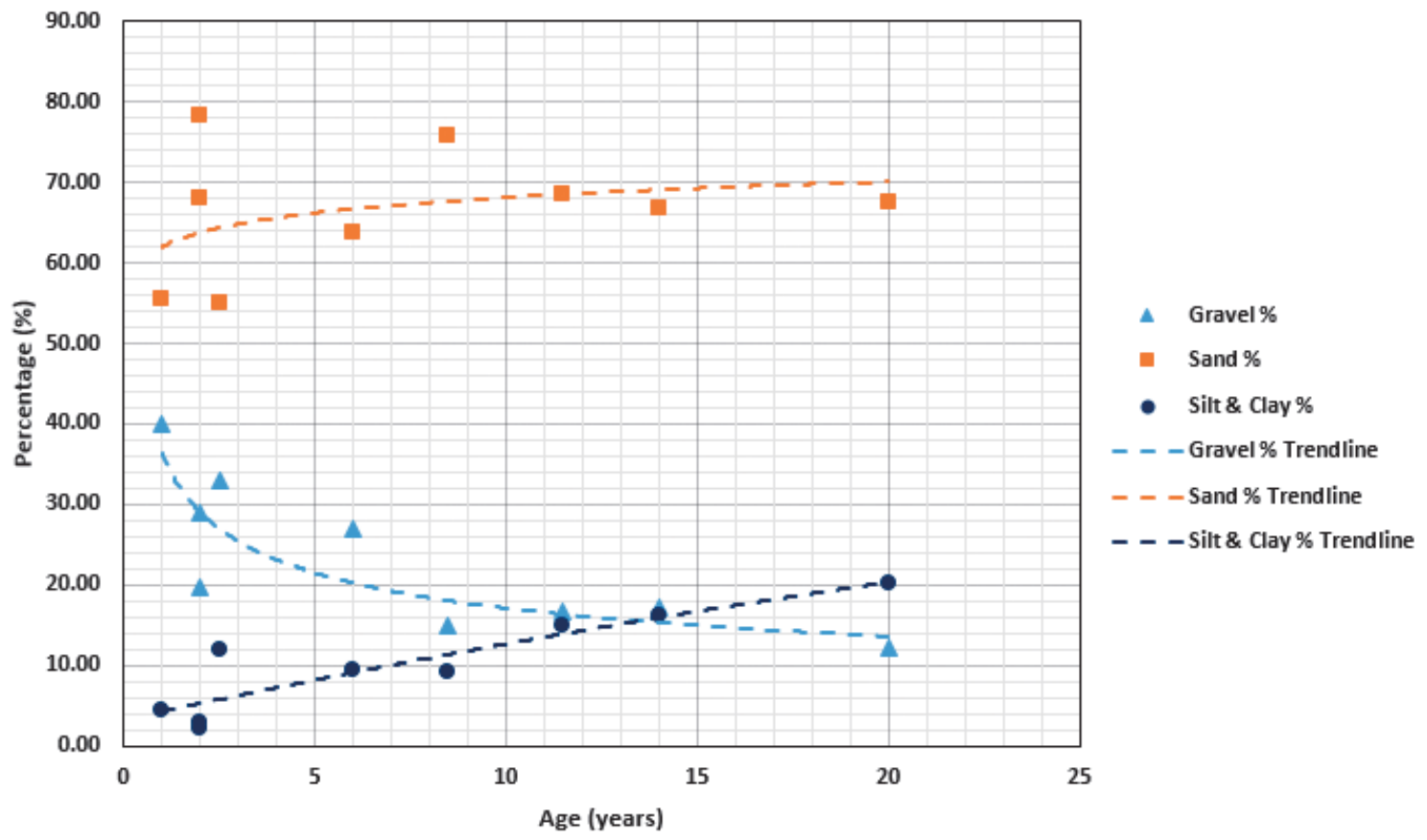

Figure 5 - Variation of Percentage of Soil Components with Age of MSW

\subsection{Specific Gravity Tests}

MSW oven dried samples passing through 2 $\mathrm{mm}$ sieve was selected for this test using large pycnometers. A comparison of specific gravity of MSW of the present study with the available literature is shown in Figure 6. These observations clearly exhibit an increasing trend of specific gravity values with the fill age. The increase in specific gravity is mainly attributed to less organic matter content due to the completion of biodegradation of MSW with age. As the MSW transforms into a type of soil with time, a value of 2.65 for specific gravity of MSW is proposed as an upper bound. This value is proposed considering the specific gravity values of Sri Lankan lateritic soils which are generally in the range of 2.65 to 2.70 . An increasing trend could be observed for Jaffna samples with a promising $R^{2}$ of about 0.9 . This observation is validated with the findings from literature as marked in Figure 6. 


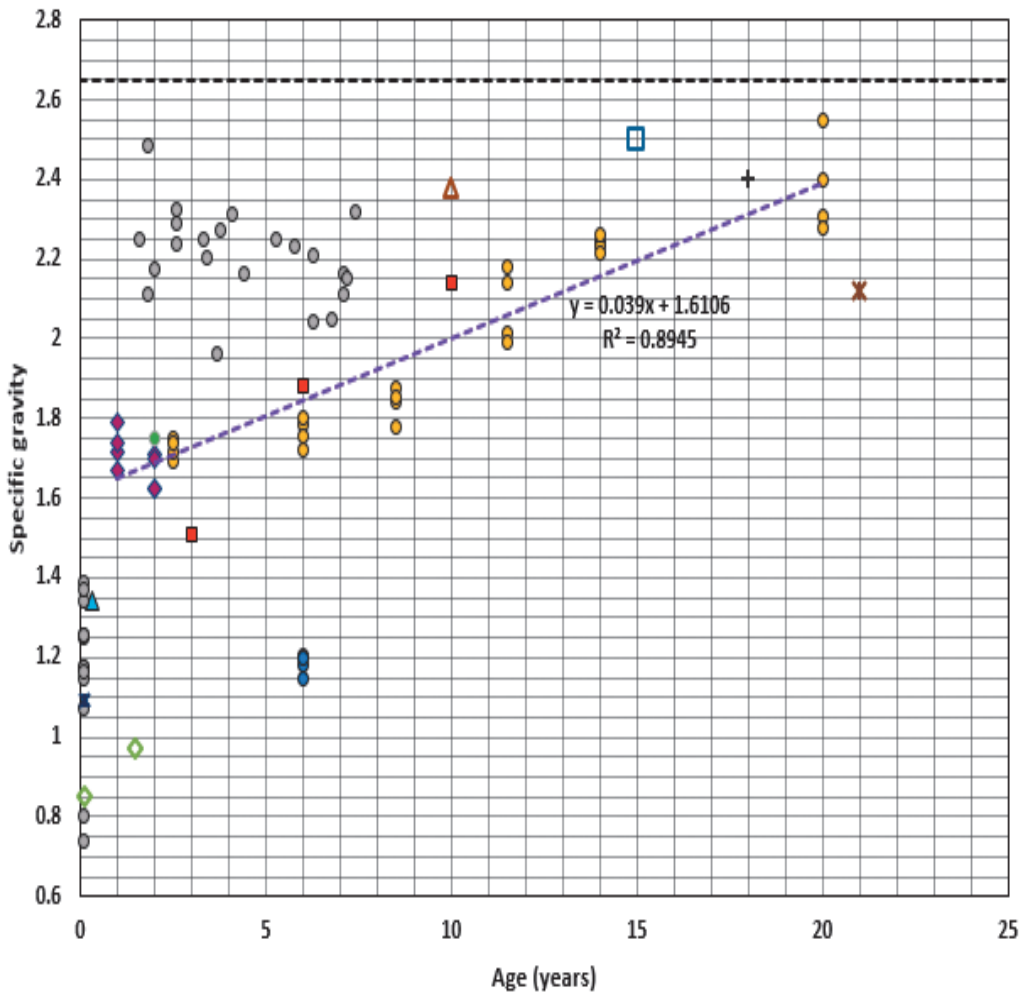

- Jaffna (Current study)

- Jaffna (Burnt) (current study)

- Orchard hills landfill (Reddy et al 2009)

- Seeduwa (Nawagamuwa and Nuwansiri 2014)

$\Delta \quad$ Negombo (Nawagamuwa and Nuwansiri 2014)

+ Madampitiya (Nawagamuwa and Nuwansiri 2014)

x Bloemendhal (Nawagamuwa and Nuwansiri 2014)

- Karadiyana (Current study)

— Beifing (Wu et al 2012)

$\Delta \quad$ Breitmeyer 2011

- Santa Maria Regional Landfill (Yesiller et al 2014)

x USA (Reddy et al 2011)

- Matara (current study)

Specific gravity of Srilankan lateritic soils

------Trendline (Current study)

Figure 6 - Comparison of Specific Gravity Values in the Present Study with Literature [4], [14], [16], [17], [18], [19]

\subsection{Atterberg Limits Tests}

The air dried MSW samples passing through $0.425 \mathrm{~mm}$ sieve were selected for this test. Variation of Atterberg limits of MSW samples is shown Figure 7 and the Atterberg limits show a decreasing trend with age. This observation contradicts with the observations in Figure 4 where an increasing trend of silt and clay content was observed with age. The decrease in Atterberg limits could be mainly due to the presence of more silt than clay.

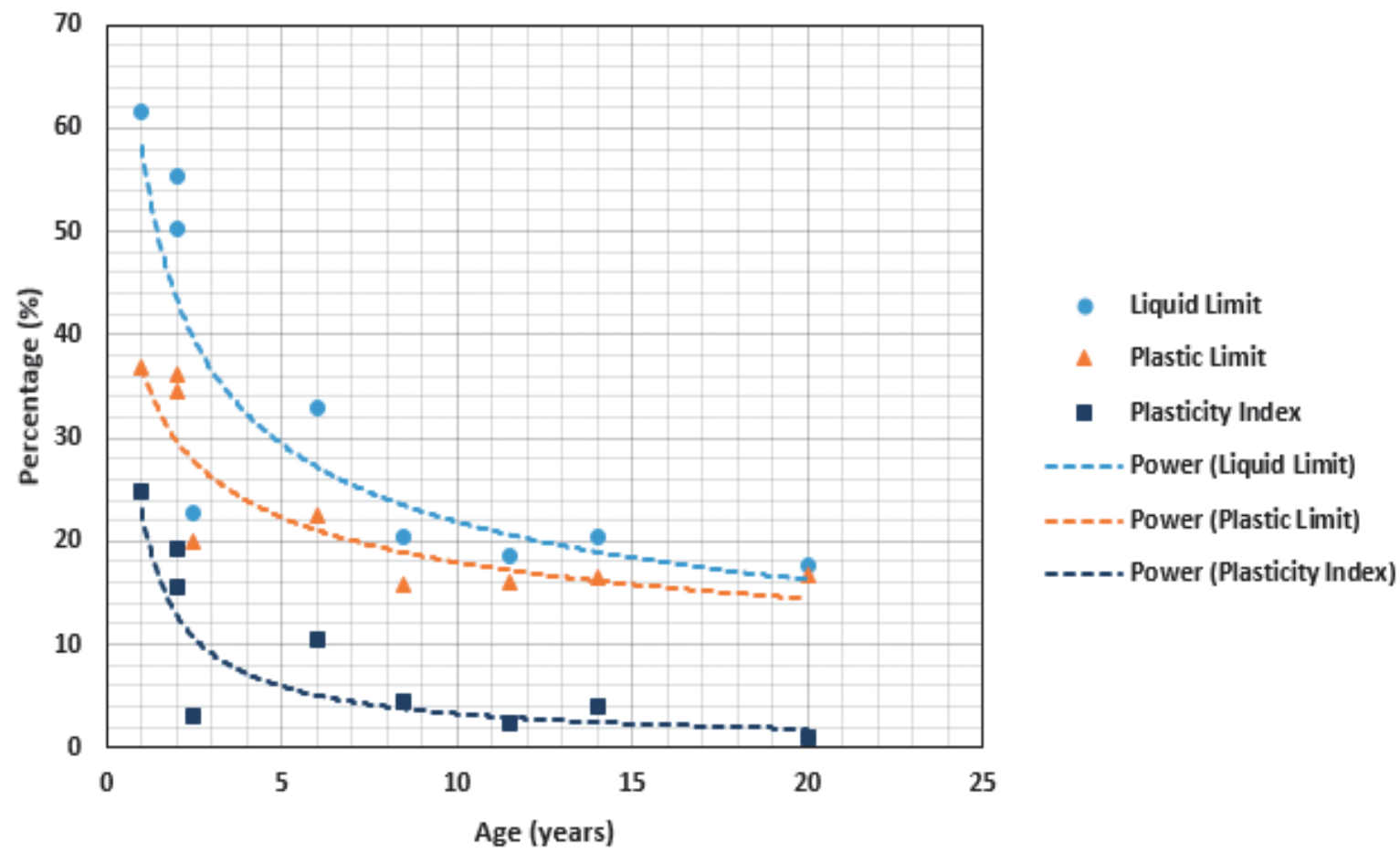

Figure 7 - Variation of Atterberg Limits with Fill Age of MSW 


\subsection{Proctor Compaction Tests}

The method A of ASTM D 698 was used with a $101.6 \mathrm{~mm}$ diameter mould with MSW samples passing through $4.75 \mathrm{~mm}$ sieve for this test. Variation of the optimum moisture content (OMC) and the maximum dry density (MDD) of MSW samples are shown in Figure 8. In this plot, OMC shows a decreasing trend, while MDD shows an increasing trend with the fill age of MSW. The increase in MDD could be due to the increase in transforming the particles into soil particles. The increase in specific gravity with age is another similar situation observed in Figure 5.

\subsection{Permeability Tests}

Variation of hydraulic conductivity of Jaffna and Karadiyana MSW samples are shown in

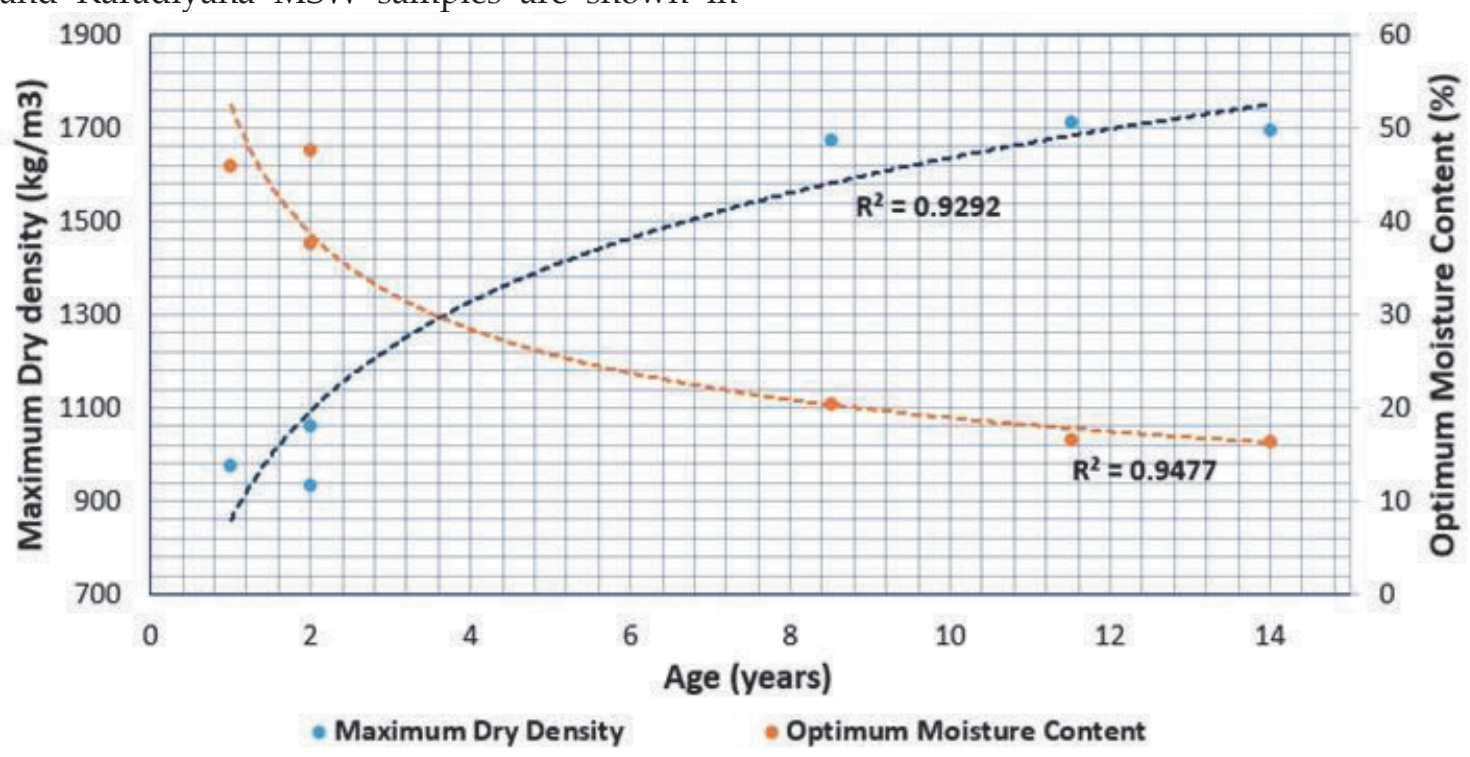

Figure 8 - Variation of Optimum Moisture Content and Maximum Dry Density with Age of MSW

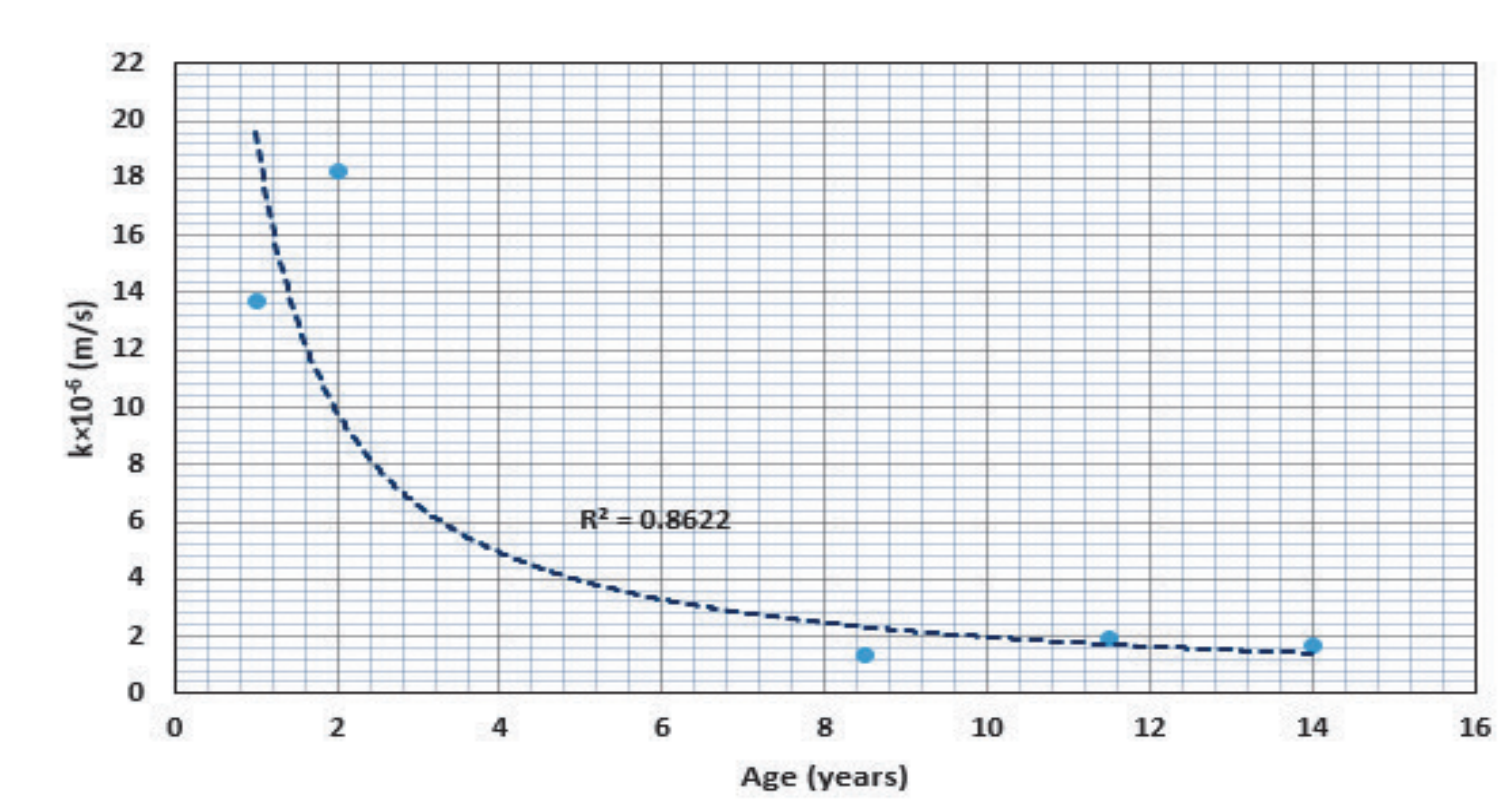

Figure 9 - Variation of Hydraulic Conductivity with Age of MSW
Figure 9. These samples were prepared at the Maximum Dry Density and Optimum Moisture Content of individual values obtained in Figure 8. Hydraulic conductivity of MSW shows a decreasing trend with the fill age of MSW. The decrease in hydraulic conductivity with fill age of MSW can be attributed to reduction of particle size with degradation, increased percentage of fines, and the higher density attainment with age. The values of hydraulic conductivity of MSW ranges between $1.33 \times 10^{-6}$ $\mathrm{m} / \mathrm{s}$ and $1.82 \times 10^{-5} \mathrm{~m} / \mathrm{s}$, which is consistent with the values reported by Reddy et al., 2009 [4] and Machado et al., 2010 [15] where it ranged between $10^{-5} \mathrm{~m} / \mathrm{s}$ and $10^{-8} \mathrm{~m} / \mathrm{s}$. 


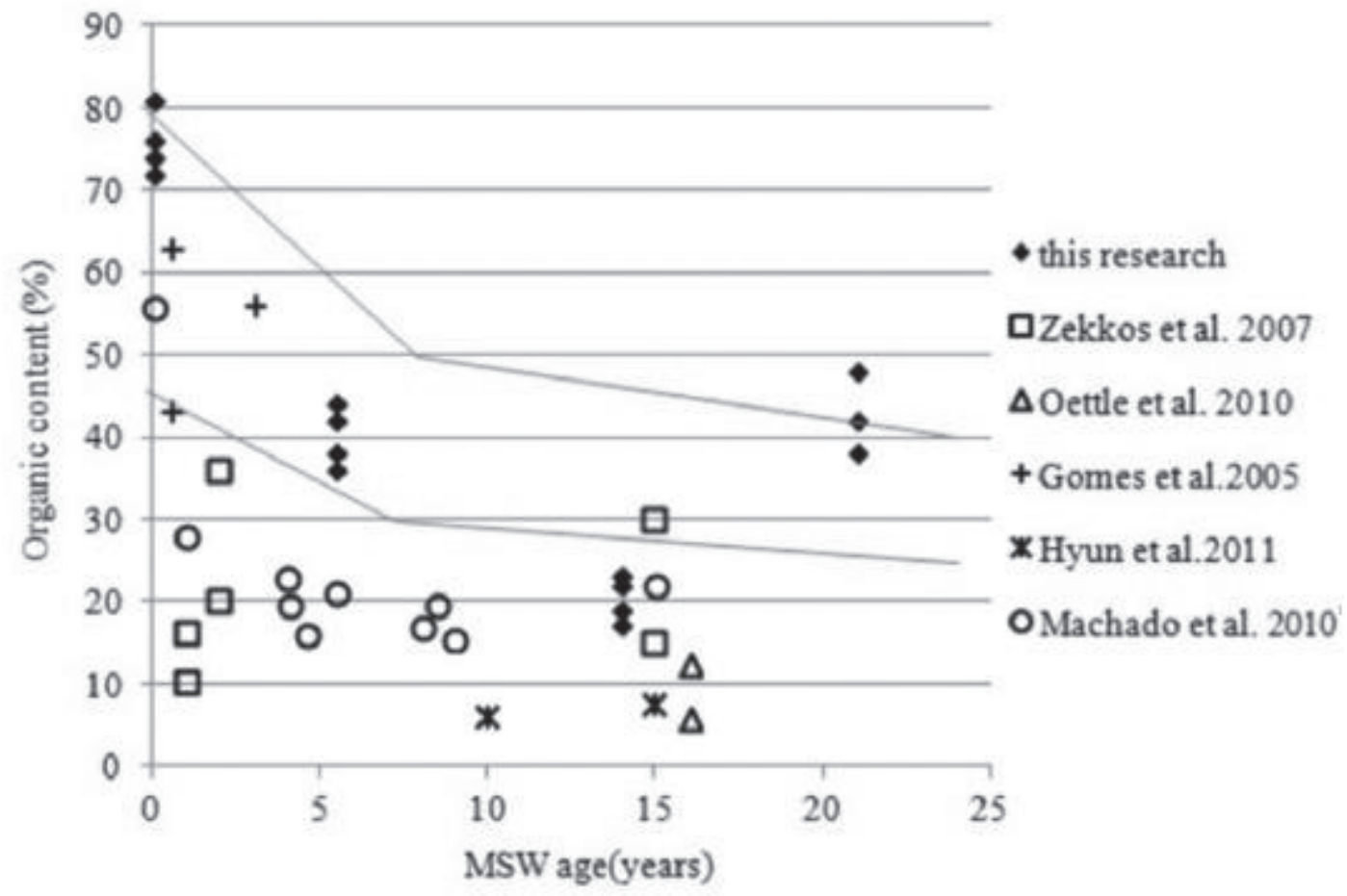

Figure 10 - Comparison of Organic Content Reported in Literature with the Findings of this Study (Some Data was Extracted from Shariatmadari et al., 2014 [13]).

\subsection{Organic Content Tests}

Organic test results were compared with the available literature and the results are shown in Figure 10. These findings confirm that there is a decreasing trend of organic content with age. This could be due to the biodegradation with age

\subsection{Direct Shear Tests}

MSW samples were tested at the corresponding Maximum Dry Density and Optimum Moisture Content values of each sample in the direct shear apparatus. Variation of the cohesion and friction angle of MSW samples with fill age are shown in Figure 11. The variation of angle of friction shows a minimum while the cohesion values show a maximum trend at the age of around $7-8$ years. This could be due to heterogeneity nature of the samples as the composition of these samples consists of fiber and plastic materials and the decomposition is a very slow and irregular process on these materials. The fiber and plastic materials generally pose a low frictional resistance although they do provide a reinforcement effect leading to a high mobilized cohesion. The direct shear test results do not show an increasing or decreasing trend. This variation is due to the composition of MSW changes in fiber and plastic materials with the fill age.

With age, biodegradation increases and hence the larger particles become smaller and due to organic matter, cohesion could increase. However, these organic matters could deteriorate and be less prominent in very old samples. This could change the cohesion from a lower level to a higher level, and again to lower levels. These results could be validated with insitu direct shear testing with a larger shear box.

Table 2 and Table 3 summarize the findings from the above tests conducted on 10 samples obtained from three different locations in Sri Lanka. 


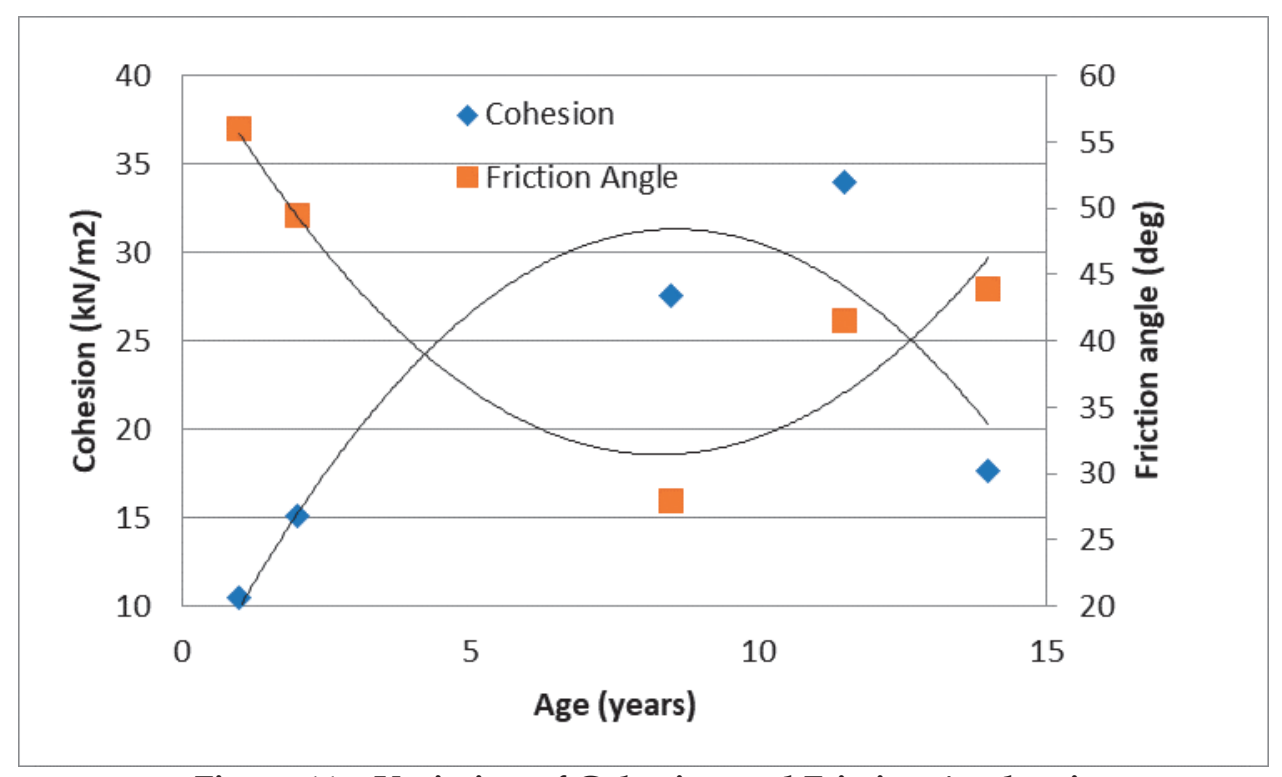

Figure 11 - Variation of Cohesion and Friction Angle wit

h Age (using Direct Shear Tests)

Table 2 - Summary of Results Obtained from Atterberg Limits and Proctor Compaction Tests

\begin{tabular}{|c|c|c|c|c|c|}
\hline $\begin{array}{c}\text { Identification } \\
\text { of MSW } \\
\text { sample }\end{array}$ & Age (years) & $\begin{array}{c}\text { Liquid Limit } \\
(\%)\end{array}$ & $\begin{array}{c}\text { Plastic Limit } \\
(\%)\end{array}$ & $\begin{array}{c}\text { Optimum } \\
\text { Moisture } \\
\text { Content }(\%)\end{array}$ & $\begin{array}{c}\text { Maximum } \\
\text { Dry Density } \\
\left(\mathrm{kg} / \mathrm{m}^{3}\right)\end{array}$ \\
\hline Jaffna 1 & $<5$ & 22.8 & 19.9 & - & - \\
\hline Jaffna 2 & $5-7$ & 33.0 & 22.6 & - & - \\
\hline Jaffna 3 & $7-10$ & 20.4 & 15.9 & 20.3 & 1674 \\
\hline Jaffna 4 & $10-13$ & 18.5 & 16.1 & 16.7 & 1714 \\
\hline Jaffna 5 & $13-15$ & 20.5 & 16.5 & 16.5 & 1696 \\
\hline Jaffna 6 & $15<$ & 17.7 & 16.6 & - & - \\
\hline Jaffna 7 & $5-7$ & - & - & - & - \\
\hline Karadiyana 1 & 1 & 61.7 & 36.8 & 46.0 & 979 \\
\hline Karadiyana 2 & 2 & 50.2 & 34.6 & 47.6 & 933 \\
\hline Matara & $1-3$ & 55.3 & 36.0 & 37.7 & 1063 \\
\hline
\end{tabular}

Table 3 - Summary of Results Obtained from Specific Gravity, Permeability and Direct Shear Tests

\begin{tabular}{|c|c|c|c|c|c|}
\hline $\begin{array}{c}\text { Identification } \\
\text { of MSW } \\
\text { sample }\end{array}$ & Age (years) & $\begin{array}{c}\text { Specific } \\
\text { Gravity }\end{array}$ & $\begin{array}{c}\text { Hydraulic } \\
\text { Conductivity } \\
(\mathrm{m} / \mathrm{s})\end{array}$ & $\begin{array}{c}\text { Cohesion } \\
\left(\mathrm{kN} / \mathrm{m}^{2}\right)\end{array}$ & $\begin{array}{c}\text { Angle of } \\
\text { Friction } \\
(\mathrm{deg})\end{array}$ \\
\hline Jaffna 1 & $<5$ & 1.72 & - & - & - \\
\hline Jaffna 2 & $5-7$ & 1.77 & - & - & - \\
\hline Jaffna 3 & $7-10$ & 1.84 & $1.33 \times 10^{-6}$ & 27.6 & 28 \\
\hline Jaffna 4 & $10-13$ & 2.08 & $1.90 \times 10^{-6}$ & 34.0 & 41.5 \\
\hline Jaffna 5 & $13-15$ & 2.24 & $1.71 \times 10^{-6}$ & 17.7 & 44 \\
\hline Jaffna 6 & $15<$ & 2.38 & - & - & - \\
\hline Jaffna 7 & $5-7$ & 1.18 & - & - & - \\
\hline Karadiyana 1 & 1 & 1.73 & $1.37 \times 10^{-5}$ & 10.5 & 56 \\
\hline Karadiyana 2 & 2 & 1.66 & $1.82 \times 10^{-5}$ & 15.1 & 49.5 \\
\hline Matara & $1-3$ & 1.75 & - & - & - \\
\hline
\end{tabular}




\section{Conclusions}

Variation of geotechnical properties of MSW with fill age is presented in this study. Particle size distribution has shown that the particle size decreases, hence waste homogeneity increases with fill age.

Atterberg limit tests have shown that the liquid limit $(61 \%$ to $17 \%)$, plastic limit (36\% to $15 \%)$, and plasticity index decrease with fill age. This variation could be due to transformation of MSW into soil formations as indicated in specific gravity relationship.

Proctor compaction tests have shown that the optimum moisture content decreases $(47 \%$ to $16 \%$ ) as porous material content decreases due to degradation, while maximum dry density increases $\left(933 \mathrm{~kg} / \mathrm{m}^{3}\right.$ to $\left.1714 \mathrm{~kg} / \mathrm{m}^{3}\right)$. This is justified with specific gravity values.

Permeability tests have shown that the hydraulic conductivity decreases $\left(1.8 \times 10^{-5} \mathrm{~m} / \mathrm{s}\right.$ to $\left.1.3 \times 10^{-6} \mathrm{~m} / \mathrm{s}\right)$, hence water retention increases with fill age. This is due to the reduction of particle sizes with degradation, and hence increasing the percentages of fines.

However, direct shear tests do not show an increasing or decreasing trend. This variation is due to composition of MSW changing in fiber and plastic materials with fill age.

Specific gravity of MSW increases (1.66 to 2.38) with fill age as organic matter decreases due to biodegradation. This observation is compared with available literature and observed to be a promising relationship and it must be validated with further experimental findings.

\section{Acknowledgement}

The staff members of the Soil Mechanics Laboratory of Department of Civil Engineering, University of Moratuwa, Sri Lanka and the officials of relevant municipal councils are kindly acknowledged for their invaluable support and approvals.

\section{References}

1. Chen, Y. M, Zhan, T. L, Wei, H. Y, and Ke, H., "Aging and Compressibility of Municipal Solid Wastes", Waste Management, 29:86-95, 2009.

2. Zhan, T. L., Chen, Y. M., \& Ling, W. A., "Shear Strength Characterization of Municipal Solid
Waste at the Suzhou Landfill, China", Engineering Geology, 97:97-111, 2008.

3. Reddy, K. R, Gangathulasi, J., Parakalla, N. S, Hettiarachchi, H., Bogner, J., and Lagier, T., "Compressibility and Shear Strength of Municipal Solid Waste under Short-Term Leachate Recirculation Operations", Waste Management and Research, 27:578-587, 2009.

4. Haque, M. A., Dynamic Characteristics and Stability Analysis of Municipal Solid Waste in Bioreactor Landfills, PhD Thesis, Faculty of the Graduate School, University of Texas, Arlington, 2007.

5. Dixon, N., Russell, D., and Jones, V., "Engineering Properties of Municipal Solid Waste", Geotextiles and Geomembranes, 23:205-233, 2005.

6. https://www.mapofworld.com/, Visited, 2020/06/02.

7. ASTM D 422, "Standard Test Method for Particle Size Analysis of Soils", Annual Book of ASTM Standards. American Society for Testing and Materials, West Conshohocken, PA, 1963.

8. ASTM D 698, "Standard Test Method for Moisture-Density Relations of Soils and SoilAggregate Mixtures using $5.5-\mathrm{lb} \quad(2.49-\mathrm{kg})$ Rammer and 12-in (305-mm) Drop", Annual Book of ASTM Standards, American Society for Testing and Materials, West Conshohocken, PA, 1978.

9. ASTM D 854, “Standard Test Method for Specific Gravity of Soils", Annual Book of ASTM Standards. American Society for Testing and Materials, West Conshohocken, PA, 1983.

10.ASTM D 2434, "Standard Test Method for Permeability of Granular Soils (Constant Head)", Annual Book of ASTM Standards, American Society for Testing and Materials, West Conshohocken, PA, 1968.

11.ASTM D 3080, "Standard Test Method for Direct Shear Test of Soils under Consolidated Drained Conditions", Annual Book of ASTM Standards. American Society for Testing and Materials, West Conshohocken, PA, 1972.

12.ASTM D 4318, (1983), “Standard Test Method for Liquid Limit, Plastic Limit and Plasticity Index of Soils", Annual Book of ASTM Standards. American Society for Testing and Materials, West Conshohocken, PA.

13.Shariatmadari, N., Sadeghpour, A. H., \& Razaghian, F., "Effects of Aging on Shear Strength Behavior of Municipal Solid Waste", International Journal of Civil Engineering, Geotechnical Engineering, 226-237, 2014. 
14.Wu, H., Wang, H., Zhao, Y., Chen, T., and Lu, W., "Evolution of Unsaturated Hydraulic Properties of Municipal Solid Waste with Landfill Depth and Age", Waste Management, 32:463-470, 2012.

15.Machado, S. L., Karimpour-Fard, M., Shariatmadari, N., Carvalho, M. F., \& Nascimento, J. C., "Evaluation of the Geotechnical Properties of MSW in Two Brazilian Landfills", Waste Management, 30:2579-2591, 2010.

16.Nawagamuwa, U. P., and Nuwansiri, R. W, "Compaction Characteristics of Municipal Solid Wastes at Open Dumpsites in Sri Lanka", Proceedings of Geo-Shanghai 2014 International Conference, May 26-28, 2014, Shanghai, China (pp 110 - 119), 2014.

17.Breitmeyer, R. J., Hydraulic Characterization of Municipal Solid Waste, Ph.D. Dissertation, University of Wisconsin, Madison, WI, 2011.

18. Yesiller, N., Hanson, J. L., Cox, J. T., and Noce D., E., "Determination of Specific Gravity of Municipal Solid Waste", Waste Management, 34:848-858, 2014.

19.Reddy, K. R., Hettiarachchi, H., Gangathulasi, J., and Bogner, J., "Geotechnical Properties of Municipal Solid Waste at Different Phases of Biodegradation", Waste Management, 31:2275-2286, 2011. 